\title{
Impact of Economic Freedom and Corruption Perceptions Index on Foreign Direct Investment in Vietnam
}

\author{
Nguyen Huu Cung, \\ Nguyen Thi Hong Nhung, \\ Hanoi University of Industry, Hanoi, Vietnam
}

URL:http://dx.doi.org/10.19044/esj.2020.v16n10p25

\begin{abstract}
Foreign direct investment is an important source of investment capital that is indispensable to contribute to each country's total investment capital. FDI attraction has always been of special interest to governments in both developed and developing countries. The empirical method was employed on a secondary time series data set during the period 1999-2018 to determine the impact of economic freedom index and corruption perceptions index on foreign direct investment in Vietnam by using the linear approach. The empirical results show that the relationship between corruption perceptions index and foreign direct investment is a positive sign at a $1 \%$ significant level. The effect of economic freedom index on foreign direct investment has a positive effect at a 5\% significant level.
\end{abstract}

Keywords: Economic freedom index, Corruption perceptions index, FDI, Vietnam

\section{Introduction}

Foreign direct investment (FDI) is always an important source of investment capital for any country whether that is the developed or developing country. Practical evidence is that countries and territories often improve their national competitiveness in attracting FDI with highly competitive policies on economic, political, social, diplomatic, and international integration. The terminology FDI has been around for a long time when there has been a movement of capital flows from one country to another to achieve optimal economic benefits and even political and economic expansion. What is FDI? The IMF and OECD define that foreign direct investment shows the target of collecting a sustainable interest by the resident entity in one economy ("direct investor") in an entity resident in an economy other than that of the investor ("direct investment enterprise"). Another definition of the WTO also states 
that a behavior which an investor of the home country purchases any asset in the host country with the purpose of managing this asset called foreign direct investment. The management dimension is what distinguishes FDI from portfolio investment in foreign stocks, bonds and other financial instruments. In most instances, both the investor and the asset it manages abroad are business firms. In such cases, the investor is typically referred to as the "parent firm" and the asset as the "affiliate" or "subsidiary." These two definitions show the nature, characteristics and role of FDI, and especially the cause of the flow of FDI flows from one country to another.

FDI not only provides the optimal benefits as expected for the home country's enterprises, but also creates opportunities to receive benefits for the host country in most fields of the economy. For the host country, Nguyen (2019) presents and analyzes the received benefits in attracting FDI inflows. FDI contributes a large amount of capital to the economy. Through FDI, countries receive more modern or different technologies than domestic ones. FDI stimulates the enhancement of corporate and national governance capacity. FDI contributes to promoting economic restructuring. FDI contributes to developing human resources and job creation. FDI contributes to the state budget. In another study on the impact of FDI on economic growth in Vietnam, Nguyen (2019) analyzes the roles of FDI in the host country and pointed out some benefits that the host country could be received in several fields such as economics, technology, foreign affairs, and society. The results of these two studies could also partly explain the attractiveness of FDI inflows, and the fact that developed and developing countries always create competitive advantages to attract FDI inflows. How to attract FDI? To attract FDI inflows, the developed countries as well as developing countries is based on four main groups of factors such as economic, social, political, policy (Franklin and Ahmed, 1978).

Vietnam applied the Law on Foreign Investment since 1987. Over the past three decades, in order to make better use of FDI inflows for socioeconomic development and creates linkages with the international economies, Vietnam has frequently had preferential policies to attract FDI into Vietnam for each specific period. The objective of Vietnam's preferential policies is to attract foreign investment in general and FDI in particular, contributes to promoting economic growth, upgrading technology, improving management capacity, creating more jobs, improving social justice, and other goals. Among all preferential policies in Vietnam for FDI, tax incentives and a reduction of tax burden have actually contributed to a favorable investment environment in attracting FDI inflows. According to statistical data, as a result of the preferential policies in FDI attraction, Vietnam has attracted 29,792 projects with a total accumulated registered capital of about USD 400 billion from 1987 to the end of 2018. Moreover, as a percentage of total investment capital, 
FDI accounted for an increasing proportion over the years and achieved $23.4 \%$ in 2018. The question is, besides the tax incentives, what factors affect the attraction of FDI inflows into Vietnam?

The papers are reviewed by the authors in this article in Vietnam and other countries which have not found any result researching on the impact of factors as economic freedom index and corruption perceptions index on FDI inflows. This is the gap that the article finds to carry out this study. Within the scope of this article, the author conducted a regression analysis on the impact of economic freedom index and corruption perceptions index on FDI inflows in Vietnam.

\section{Literature Reviews}

Empirical evidence in countries shows that a linkage or non-relation between independent variables and FDI could be a positive or negative sign. In an empirical analysis on the determinants of FDI in Afghanistan, Wani and Rehman (2017) employed a time series data set by using the OLS method. The results showed that the effect of total debt service, total external debt, gross domestic product and gross fixed capital on FDI is a strong positive sign. Moreover, the relationship between inflation and FDI has a negative effect. In an empirical analysis on the determinants of FDI in China, Ali and Guo (2005) surveyed 22 enterprises operating in China. The results showed that market size has a strong positive effect and significant on FDI into China, especially for US firms. At the same time, local, export-oriented, and Asian firms placed high importance on low labor costs as a main factor to attract these firms to invest in China. A cross-sectional analysis on the determinants of FDI flows to developing countries, Demirhan and Masca (2008) employed average value of all data for the years 2000-2004 on 38 developing countries. The empirical results in the main model found that the effect of growth rate of per capita, telephone main lines and degree of openness on FDI has a positive sign and significant, meanwhile inflation and tax rate have a negative effect and significant on FDI. In addition, the article also found that the relationship between labor cost and FDI has a positive impact and insignificant while risk and FDI has negative sign and insignificant. Ang (2008) studied on the determinants of foreign direct investment in Malaysia by using an annual time series data set for the period 1960-2005. The findings showed that the relationship between real GDP and FDI inflows has a positive effect and significant, at the same time, growth rate of GDP has a small positive impact on inward FDI. Another study on the determinants of FDI in Nigeria and the findings showed that there are several main factors affecting FDI such as GDP growth, macro instability, financial development, exchange rate, inflation, and discount rate (Enisan, 2017). Mohiuddin and Salam (2011) employed a data set of macro indicators during the period from FY 1973-74 to FY 2007-08 and 
the findings showed that the effect of exchange rate and real GDP on FDI inflows has a positive sign. A study of Kumari and Sharma (2017) used an unbalanced panel data set for the years 1990-2012 and the results found that the effect of market size, trade openness, interest rate, and human capital on FDI inflows is a positive sign and significant, especially market size is a most powerful factor affecting FDI inflows into developing countries. Cieślik (2019) performs an empirical analysis by using a panel data set to identify the determinants of multinational activity of enterprises from the OECD member states in Poland for the years 1996-2015. The empirical result finds that the vertical motive is the primary reason of multinational firms of the OECD member states to invest directly in Poland.

In Vietnam, there are mainly a number of studies on the effect of FDI on economic growth. In an empirical study on the relationship between FDI and economic growth in Vietnam by using a time series data set for the years from 1990 to 2015 (Ha et al., 2017) and the findings showed that the relationship between FDI inflows and GDP growth has a positive effect and significant. This means that FDI inflows have an important role in contributing for the rapid growth of GDP in Vietnam. A panel data set for the years 19952006 was employed by Hoang et al. (2010) to analyze the effect of FDI on economic growth in Vietnam's sixty-one provinces, and the empirical results found that the relationship between FDI and economic growth has a positive sign and significant. A recent empirical study on the impact of FDI (net inflows) on economic growth in Vietnam employed a secondary time series data set for the years 1995-2018 by using the linear model and the results found that the effect of FDI (net inflows), export of goods and services (\% of GDP), and financial freedom index on GDP (current) is a positive sign and significant. Moreover, investment freedom index and annual inflation rate have a negative effect on GDP (current). In an empirical study on the relationship between tax burden and FDI in Vietnam, Nguyen and Liu (2013) employed a secondary time series data set during the period 1999-2011 by using the linear model and OLS method. The results found that the effect of tax burden on FDI flows is a negative sign and significant while the impact of unit labor costs and inflation index on FDI flows is a positive sign and significant at a $1 \%$ significance level. Another study analyzes the role of GDP at current prices in attracting FDI inflows into Vietnam for the years 20032018 and the results have shown that the relationship between real GDP and FDI has a positive effect and significant at $1 \%$ significant level (Nguyen, 2019).

From literature reviews in Vietnam and other countries, within the scope of this article, the authors temporarily draws three conclusions. Firstly, the impact of factors on FDI inflows could be a positive or a negative sign. The relationship between FDI inflows and independent variables has a positive 
effect such as total debt service, total external debt, gross fixed capital, market size, low labor costs, growth rate of per capita, telephone main lines, degree of openness, real GDP, growth rate of GDP, macro instability, financial development, exchange rate, discount rate, trade openness, interest rate, and human capital. The relationship between FDI inflows and independent variables has a negative effect such as inflation, risk. Secondly, there are few research results on the relationship between the determinants of FDI inflows in Vietnam. Finally, none of the studies has looked at the effect of economic freedom index and corruption perceptions index on FDI inflows. This is a good opportunity for this article to add a new study to fill these gaps in the literature. Therefore, the main goal of the article is to determine the statistically significant parameters on the impact of economic freedom index and corruption perceptions index on FDI inflows in Vietnam by using the linear model and OLS method.

\section{Data and Model}

As reviewed above, there are a number of different groups of factors effecting FDI inflows into each country such as economic, technology, social, political. This has been proved in economic theory as well as empirical evidence. An empirical study is used to determine the impact of economic freedom index and corruption perceptions index and FDI inflows in Vietnam. Within the scope of this article, the authors perform a regression and correlation analysis by using a linear model and the OLS method. The article employed a secondary time series data set during the period 1999-2018 by using economic freedom index, corruption perceptions index and FDI (net inflows) was obtained from the World Bank, the Heritage Foundation, and Transparency International - The Global Anti-Corruption. If these two indexes are higher over time, a positive impact in attracting FDI inflows is always expected.

The authors use a correlation and regression analysis to analyze the relationship between two dependent variables (economic freedom index, corruption perceptions index) and an independent variable (FDI, net inflows). FDI is dependent while (ECOFREE and CORRUP) are independent. The linear regression model has the following form.

$\mathrm{FDI}=\mathrm{F}(\mathrm{ECOFREE}, \mathrm{CORRUP})$

$\mathrm{FDI}=\beta_{1}+\beta_{2} \mathrm{ECOFREE}+\beta_{3} \mathrm{CORRUP}+\varepsilon_{\mathrm{t}}$

Where, FDI = Foreign Direct Investment, net inflows (BoP, current, Bill.US\$)

Where, $\beta_{1}$ is Intercept Term and $\beta_{2}, \beta_{3}$ are Coefficients 
ECOFREE $=$ Economic Freedom Index (score)

CORRUP $=$ Corruption Perceptions Index (score)

$\varepsilon=$ Error Variable

The regression results show that the model has statistical significance through indicators such as $\operatorname{Prob}(\mathrm{F}$-statistic $)=0.000000<\alpha=5 \%=0.05$, block coefficient $\beta_{1}, \beta_{2}$ and $\beta_{3}$ to be consistent with the economic theory. The value of R-squared and Adjusted R-squared is large. Due to Durbin-Watson test to be too small and smaller than the value $\mathrm{d}_{\mathrm{u}}$ (at $5 \%$ significance level), therefore this model has an auto-correlation phenomena grade 1 .

To overcome the autocorrelation phenomenon, the authors use the generalized differential equation to overcome the auto-correlation phenomenon of the original model. The linear regression model has the following form.

$F D I_{t}-\hat{\rho} F D I_{t-1}=\hat{\beta}_{1}(1-\hat{\rho})+\hat{\beta}_{2}\left(\operatorname{ECOFREE}_{t}-\hat{\rho} \operatorname{ECOFREE}_{t-1}\right)+\hat{\beta}_{3}\left(\operatorname{CORRUP}_{-} \hat{\rho} \operatorname{CORRUP} P_{t-1}\right)+\left(\mu_{t}-\hat{\rho} \mu_{t-1}\right)$

The autocorrelation test with the extra regression:

Model has not block coefficient: $\varepsilon_{t}=\alpha_{1} \varepsilon_{t-1}+v_{t}$

Model has block coefficient: $\quad \varepsilon_{t}=\alpha_{0}+\alpha_{1} \varepsilon_{t-1}+v_{t}$

The results of Equation (3): $\mathrm{E}(-1)=0.327115$, Durbin-Watson stat $=1.717849$ The results of Equation (4): $\mathrm{E}(-1)=0.327365$, Durbin-Watson stat $=1.718175$

The regression results of Equation (2) are statistical significance. This concludes that the model is consistent with the economic theory. Through the Durbin-Watson statistics and the extra regression of Equation (3) and Equation (4), the correlation coefficient estimation grade 1 by $\hat{\rho} \cong 0.33$, to substitute into Equation (2):

$F D I_{t}-0.33 F D I_{t-1}=\hat{\beta}_{1}(1-0.33)+\hat{\beta}_{2}\left(\right.$ ECOFREE $_{t}-0.33$ ECOFREE $\left._{t-1}\right)+\hat{\beta}_{3}\left(\operatorname{CORRUP}-0.33 \mathrm{CORRUP}_{t-1}\right)+\left(\mu_{t}-0.33 \mu_{t-1}\right)$

The regression results of Equation (5) show that the general differential equation has statistical significance and to be in line with economic theory.

\section{Results and Discussion Descriptive Statistics}

The descriptive statistics on the relationship between independent variables (economic freedom index, corruption perceptions index) and FDI (net inflows) in Vietnam are presented in Table 1 below. 
Table 1. Descriptive Statistics

\begin{tabular}{lccc}
\hline \hline \multicolumn{1}{c}{ Descriptive } & Statistics & & \\
\hline \hline Mean & FDI & ECOFREE & CORRUP \\
\hline Maximum & 6.630050 & 49.05500 & 28.20000 \\
Minimum & 15.50000 & 53.10000 & 35.00000 \\
Std. Deviation & 1.298000 & 42.70000 & 24.00000 \\
Observations & 4.740617 & 3.136118 & 3.270281 \\
\hline \hline
\end{tabular}

Source: Descriptive Statistics Output of Data Collected

\section{Correlation and Regression Analysis}

\section{Correlation Analysis between FDI and Independent Variables}

The results in Table 2 below show that the correlation analysis was undertaken between FDI at current prices and explanatory variables such as economic freedom index and corruption perceptions index. The effect of economic freedom index and corruption perceptions index on FDI (net inflows) could be a positive or negative sign.

Table 2. Correlation Matrix between GDP and Independent Variables

\begin{tabular}{ccccc}
\hline \hline & & FDI & ECOFREE & CORRUP \\
\hline \hline \multirow{3}{*}{ Pearson Correlation } & FDI & 1 & & \\
& ECOFREE & 0.853381 & 1 & \\
& CORRUP & 0.895196 & 0.749138 & 1 \\
\hline
\end{tabular}

Source: Correlation Output of Data Collected

The correlation output of the collected data indicates that there is a positive relationship between FDI and two independent variables such as economic freedom index and corruption perceptions index.

Table 3. Regression Analysis Results of Equation (1)

\begin{tabular}{crcrr}
\hline \hline Variable & Coefficient & Std. Error & t-Statistic & Prob. \\
\hline \hline C & -48.09406 & 6.581303 & -7.307681 & 0.0000 \\
ECOFREE & 0.629585 & 0.193718 & 3.250008 & 0.0047 \\
CORRUP & 0.845384 & 0.185771 & 4.550685 & 0.0003 \\
\hline \hline R-squared & 0.877493 & Durbin-Watson stat & 1.303947 \\
Adjusted R-squared & 0.863080 & Prob(F-statistic) & 0.000000 \\
\hline \hline
\end{tabular}

Source: Correlation Output of Data Collected 

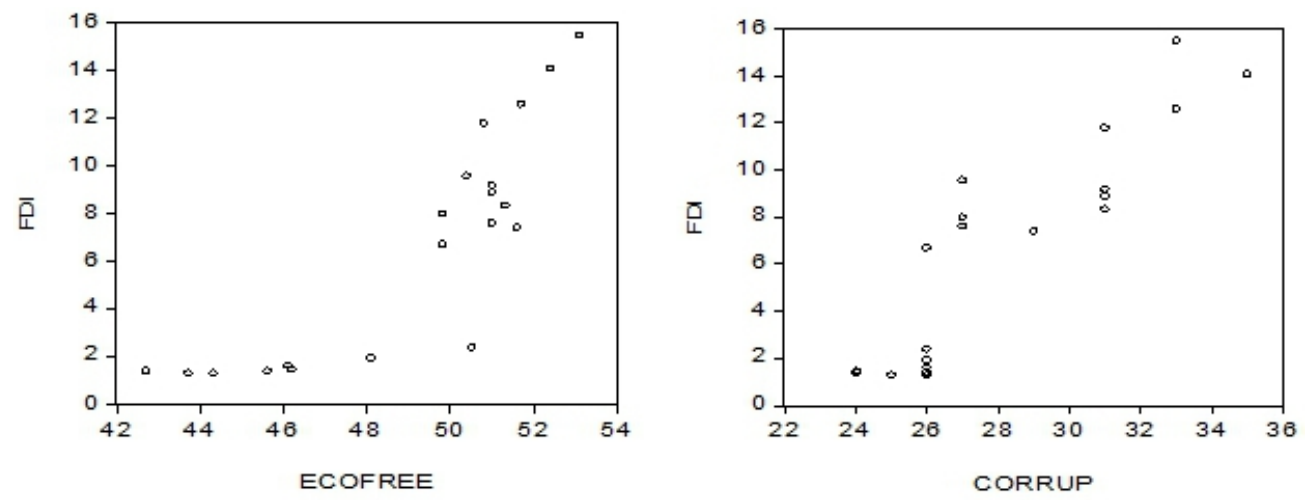

Due to $p_{-}$value of economic freedom index and corruption perceptions index is so small and less than 0.05 implies significant impact, therefore the effect of these two independent variables on FDI (net inflows) is significant. The regression results also show, $\mathrm{R}$-squared $\left(\mathrm{R}^{2}\right)=0.877493$, means that the change of the independent variables explained $87.7493 \%$ of the dependent variable's fluctuation. $\mathrm{R}^{2}$ and F-statistic are large, the regression model is appropriate. However, as analyzed above, the value of Durbin-Watson test is $\mathrm{d}=1.303947$ while the sample numbers $\mathrm{n}=20$, number of independent variable in the model $\mathrm{k}^{\prime}=2$, inferred $d_{L}=1.100$ and $d_{U}=1.537$, due to $\mathrm{d}<\mathrm{d}_{\mathrm{U}}$, concludes that the model is autocorrelation phenomena grade 1 .

Table 4. Regression Analysis Results of Equation (3)

\begin{tabular}{crccr}
\hline \hline Variable & Coefficient & Std. Error & t-Statistic & Prob. \\
\hline \hline E(-1) & 0.327115 & 0.234878 & 1.392700 & 0.1807 \\
\hline \hline R-squared & 0.096896 & Durbin-Watson stat & 1.717849 \\
Adjusted R-squared & 0.096896 & & & \\
\hline \hline
\end{tabular}

Source: Correlation Output of Data Collected

Table 5. Regression Analysis Results of Equation (4)

\begin{tabular}{crrrr}
\hline \hline Variable & Coefficient & Std. Error & t-Statistic & Prob. \\
\hline \hline $\mathrm{C}$ & 0.005201 & 0.381937 & 0.013617 & 0.9893 \\
$\mathrm{E}(-1)$ & 0.327365 & 0.242381 & 1.350619 & 0.1945 \\
\hline \hline R-squared & 0.096906 & Durbin-Watson stat & 1.718175 \\
Adjusted R-squared & 0.043783 & & & \\
\hline \hline
\end{tabular}

Source: Correlation Output of Data Collected 
Table 6. Regression Analysis Results of Equation (5)

\begin{tabular}{crrrr}
\hline \hline Variable & Coefficient & Std. Error & t-Statistic & Prob. \\
\hline \hline C & -32.89061 & 7.670752 & -4.287794 & 0.0006 \\
FREE-0.33*FREE(-1) & 0.692795 & 0.313671 & 2.208670 & 0.0421 \\
COR-0.33*COR(-1) & 0.770488 & 0.248363 & 3.102270 & 0.0068 \\
\hline \hline R-squared & 0.769395 & Durbin-Watson stat & 1.712490 \\
Adjusted R-squared & 0.740569 & Prob(F-statistic) & 0.000008 \\
\hline \hline
\end{tabular}

Source: Correlation Output of Data Collected

\section{Model Fitness}

Based on the regression results in Table 6 , sign of $\hat{\beta}_{1}, \hat{\beta}_{2}, \hat{\beta}_{3}$ are in accordance with the economic theory in the case of Vietnam. Because economic freedom index and corruption perceptions index of Vietnam tend to increase over the years in the research period. The block coefficient $\hat{\beta}_{1}$ has a negative sign, means that Vietnam adopts a closed economy, no any policy of FDI attraction and serious corruption, FDI inflows is zero. Look up the appendix of Durbin-Watson Tables at 5\% significant level, the sample numbers $\mathrm{n}=20$, number of independent variable in the model $\mathrm{k}^{\prime}=2$, inferred $d_{L}=1.100$ and $d_{U}=1.537$. Meanwhile, the value $d$ of Durbin-Watson test is $\mathrm{d}$ $=1.712490$, inferred $d_{u}=1.537<d=1.712490<4-d_{u}=2.463$. These results show that the model has not an autocorrelation phenomena grade 1 . Moreover, due to $p_{-}$value of economic freedom index and corruption perceptions index is so small, so the effect of these two factors on FDI (net inflows) is too strong. The regression results also show that $\mathrm{R}^{2}=0.769395$, which means the change of economic freedom index and corruption perceptions index explained $76.9395 \%$ of the dependent variable's fluctuation. The regression model is appropriate.

After the change of variable, the block coefficient estimate of the differential model is -32.89061 , so the block coefficient estimate of Equation (1): $\hat{\beta}_{1}=[-32.89061 /(1-0.33)]=-49.09046$. The slope estimate of the original model $\hat{\beta}_{2}=0.692795$ and $\hat{\beta}_{3}=0.770488$. $\hat{\beta}_{2}$ shows that in constant other factors, economic freedom index increases to 1 score, FDI (net inflows) increases to USD 0.692795 billion. Similarly, $\hat{\beta}_{3}$ implies that corruption perceptions index rises to 1 score, FDI (net inflows) increases to USD 0.770488 billion. Thus, the impact of corruption perceptions index on FDI (net inflows) is stronger than economic freedom index in the research period. 


\section{Corruption Perceptions Index}

Corruption is one of the most important issues that to be of special interest by many countries in both developed and developing countries. This is considered the vices affecting national development policies. Corruption could have many serious consequences in all fields of the economy, politics and society. Vietnam has always considered corruption as one of the major challenges to national stability, people's confidence, and effective use of social resources. In fact, corruption has been badly affecting Vietnam's development. Due to the bad effects of corruption, Vietnam always raises awareness about corruption and has many effective solutions to control corruption. As a result, corruption situation in Vietnam has dropped as expected and has been tightly controlled for many years. Evidence that Vietnam's corruption perceptions index has increased over the years during the period 1999-2018, for example, 26 score in 1999 increases to 33 score in 2018 (Transparency International The Global Anti-Corruption). Moreover, empirical evidence in this study also shows that corruption perceptions index has a positive effect and significant on FDI (net inflows) at a 1\% significance level. This value implies that in constant condition of other factors, a 1.0 score increase in corruption perceptions index results in USD 0.770488 billion billion increase in FDI (net inflows) into Vietnam. However, Vietnam's corruption perceptions index is increases slowly and still slower than other countries in the region (Nguyen Huu Cung, 2019). Based on the data of Transparency International - The Global Anti-Corruption, corruption perceptions index in 1999 and 2018 of Japan (60 score and 73 score), Taiwan (56 score and 63 score), South Korea ( 38 score and 57 score), Thailand (32 score and 36 score), Vietnam (26 score and 33 score). Therefore, due to achieve the national development goals in the next period, Vietnam must continue to vigorously reform the policies, a higher transparency in the fields, a stricter attitude toward corrupt behaviors, an increase in anti-corruption awareness. This result is a new finding of the author in the case study of Vietnam.

\section{Economic Freedom Index}

According to The Heritage Foundation, the index of economic freedom is an index which countries are scored based on 12 factors: property rights, judicial effectiveness, government integrity, tax burden, government spending, fiscal health, business freedom, labor freedom, monetary freedom, trade freedom, investment freedom, financial freedom. This index is increasing over time, which partly proves that the country is in the development period. The empirical evidence of this study shows that the index of economic freedom has a positive and significant effect on FDI (net inflows) at 5\% significance level. More specifically, in constant condition of other factors, a 1.0 score increase in economic freedom index results in 
approximately raise USD 0.692795 billion in FDI (net inflows) in Vietnam. However, based on the Heritage Foundation's data, Vietnam's economic freedom index is still slower than other countries in the region. Average annual in the period 1999-2018, this index of countries is 70.9 scores of Japan, 69.7 scores of South Korean, 65.8 scores of Malaysia, 64.8 scores of Thailand, 56.2 scores of Indonesia, 53.3 scores of China, 49.1 scores of Vietnam. Generally, in economic theory and practice in countries proves that the relationship between index of economic freedom and FDI inflows has a positive sign. Therefore, in the trend of international integration, in order to develop the economy in general and attract FDI inflows in both quality and quantity, Vietnam needs to continue improving the economic freedom index through 12 factors as presented above. This result is a new finding of the author in the case study of Vietnam.

\section{Conclusion}

The purpose of this paper is to determine the effect of corruption perceptions index and economic freedom index on FDI (net inflows) for the years 1999-2018 in Vietnam by using the linear model and OLS method. The results show that index of economic freedom has a positive effect and significant at a 5\% significance level while index of corruption perceptions has a significant positive effect at a $1 \%$ level of significance. As indicated above, literature reviews mainly focus on studying the factors affecting FDI inflows in different countries, such as real GDP, GDP per capita, economic growth, exports, inflation, interest rate, exchange rate, trade openness, political, and others. Thus, within the scope of the author's research that temporarily has not yet found any research results on the impact of corruption perception index and economic freedom index on FDI inflows. The authors conclude that this is a new finding in the case of Vietnam for the research period. These empirical results remind that economic development in general and FDI attraction in particular are positively affected by these two factors. Evidence that, the more developed countries like Japan, South Korea, Malaysia, China, Thailand, Indonesia, and others, all have the index of corruption perceptions and economic freedom to be higher than Vietnam. Therefore, Vietnam needs to continue improving these two factors in an upward direction in order to partly enhance national competitiveness in attracting FDI.

\section{References:}

1. Ali and Guo (2005), Determinants of FDI in China, Journal of Global Business and Technology, 1(2), 21-33.

2. Cieślik, A. (2019). Determinants of foreign direct investment from OECD countries in Poland. Eurasian Economic Review, 1-17. 
3. https://link.springer.com/article/10.1007/s40822-019-00136-y

4. Demirhan and Masca (2008), Determinants of Foreign Direct Investment Flows to Developing Countries: A Cross-Sectional Analysis, Prague Economic Paper, 2008(4), 356-369. DOI: 10.18267/j.pep.337

5. Enisan (2017), Determinants of Foreign Direct Investment in Nigeria: A Markov Regime-Switching Approach, Review of Innovation and Competitiveness, 3(1), 21-48.

6. Franklin and Ahmed (1978), The influence of policy instruments on manufacturing direct foreign investment in developing countries, Journal of International Business Studies, 9(3): 81-94.

7. Ha, Huang, Hu and Than (2017), The Impact of Foreign Direct Investment on Economic Growth: A Case Study in Vietnam 19902015, Industrial Engineering Letters, 7(4): 1-7.

8. Hoang, Wiboonchutikula and Tubtimtong (2010), Does Foreign Direct Investment Promote Economic Growth in Vietnam?, ASEAN Economic Bulletin, 27(3): 295-311.

9. James B. Ang (2008), Determinants of foreign direct investment in Malaysia, Journal of Policy Modeling, 30(2008) 185-189. DOI:10.1016/j.jpolmod.2007.06.014

10. Kumari and Sharma (2017), Determinants of Foreign Direct Investment in Developing Countries: A Panel Data Study, International Journal of Emerging Markets, 12(4), 658-682.

11. Maitena Duce (2003), Definition of Foreign Direct Investment (FDI): A methodological note, Final draft, Junly 31, 2003. Online at http://www.bis.org/publ/cgfs22bde3.pdf

12. Mohiuddin and Salam (2011), Determinants of Foreign Direct Investment in Pakistan, Journal of Independent Studies and Research_MSSE, 9(1), 117-124.

13. Nguyen (2019), Gross Domestic Product and Foreign Direct Investment: Empirical Evidence from Vietnam, European Scientific Journal, 15(31): 38-51.

14. Nguyen (2020), Impact of Foreign Direct Investment on Economic Growth in Vietnam, Advances in Management and Applied Economics, 10(2): 89-99.

15. Nguyen and Liu (2013), Tax Burden and Foreign Direct Investment: Theory and Practice in Vietnam, Advances in Management and Applied Economics, 3(3), 85-103.

16. Nguyen Huu Cung (2019), Impact of Economic Freedom Index and Corruption Perceptions Index on Corporate Income Tax Revenue in Vietnam, European Scientific Journal, 15(28): 185-196. Online at https://eujournal.org/index.php/esj/article/view/12483/12202 
17. Wani and Rehman (2017), Determinants of FDI in Afghanistan: An Empirical Analysis, Munich Personal RePEc Archive (MPRA), Paper No. 81975.

18. Online at https://mpra.ub.uni-muenchen.de/81975/

19. World Trade Organization, Trade and Foreign Direct Investment, New Report by the WTO, 9 October 1996. Online at http://www.wto.org/English/news_e/pres96_e/pr057_e.htm.

20. https://databank.worldbank.org/home.aspx

21. https://www.heritage.org/index/visualize

22. https://www.transparency.org/research/cpi/overview 